\title{
Epithelioid cell histiocytoma with SQSTM1-ALK fusion: a case report
}

Ryuko Nakayama ${ }^{1}$, Yuki Togashi ${ }^{2}$, Satoko Baba ${ }^{2}$, Yo Kaku ${ }^{3}$, Yuki Teramoto ${ }^{1}$, Takaki Sakurai ${ }^{1}$, Hironori Haga ${ }^{{ }^{*}}$ (D) and Kengo Takeuchi ${ }^{2}$

\begin{abstract}
Background: Epithelioid cell histiocytoma (ECH), which is also known as epithelioid benign fibrous histiocytoma, has been classified as a rare variant of fibrous histiocytoma (FH). However, the recent detection of ALK protein expression and/or ALK gene rearrangement in ECH suggests that it might be biologically different from conventional $\mathrm{FH}$.
\end{abstract}

Case presentation: A 27-year-old male presented with nodule on his left foot, which had been present for 5 years. A macroscopic examination revealed an exophytic, hyperkeratotic nodule on the dorsum of the left foot. Tumorectomy was performed, and a microscopic examination showed a subepidermal lesion composed of sheets of tumor cells with oval to round nuclei and ill-defined eosinophilic cytoplasm. The tumor cells were diffusely positive for factor XIIla and ALK, but were negative for AE1/AE3 keratin, alpha-smooth muscle actin, CD30, CD34, CD68, PU.1, melan A, MITF, and S-100 protein. ALK immunostaining showed a diffuse cytoplasmic staining pattern. ALK fluorescence in situ hybridization demonstrated break-apart signals, which was suggestive of ALK rearrangement. A 5'-rapid amplification of CDNA ends assay detected SQSTM1-ALK fusion, in which exon 5 of the SQSTM1 gene was fused to exon 20 of the ALK gene. The patient was free from recurrence and distant metastasis at the 1-year of follow-up.

Conclusion: We were able to demonstrate the SQSTM1-ALK fusion gene in ECH. Practically, detecting immunopositivity for ALK and appropriate cell-lineage markers are the key to diagnosing ECH.

Keywords: Epithelioid cell histiocytoma, Fibrous histiocytoma, ALK gene rearrangement, SQSTM1-ALK gene fusion

\section{Background}

Epithelioid cell histiocytoma (ECH), which is also known as epithelioid benign fibrous histiocytoma, is generally considered to be an epithelioid variant of fibrous histiocytoma (FH) of the skin [1-4]. ECH is a dermal-based benign fibrohistiocytic tumor, which can mimic melanocytic, vascular, epithelial, and other histiocytic lesions. ECH usually occurs in young adults and is slightly more common in males than females [2]. ECH most commonly arises on the extremities as an erythematous dermal nodule. Although ECH is considered to be benign, cases involving multiple lesions or metastasis have also been reported $[3,5]$. Histologically, this tumor is characterized by epithelioid cell proliferation in the dermis, surrounded by epidermal collarette. This pattern of epidermal changes can simulate Spitz nevus (Spitz tumor), but the tumor cells are negative for melanocytic markers and positive for dermal dendrocytic markers, such as factor XIIIa [1, 2].

Recently, anaplastic lymphoma kinase (ALK) protein expression associated with $A L K$ rearrangement was reported in ECH [6-9]. However, in most of these studies the fusion partner gene was not reported. However, Jedrych et al. identified $V C L-A L K$ and SQSTM1-ALK fusion genes in two cases of ECH [6]. More recently, two reports presented large series of gene fusion studies on ECH $[10,11]$. Herein, we report a case of $\mathrm{ECH}$ involving SQSTM1-ALK gene fusion.

\footnotetext{
* Correspondence: haga@kuhp.kyoto-u.ac.jp

${ }^{1}$ Department of Diagnostic Pathology, Kyoto University Hospital, Kyoto, Japan Full list of author information is available at the end of the article
}

(c) The Author(s). 2018 Open Access This article is distributed under the terms of the Creative Commons Attribution 4.0 International License (http://creativecommons.org/licenses/by/4.0/), which permits unrestricted use, distribution, and reproduction in any medium, provided you give appropriate credit to the original author(s) and the source, provide a link to the Creative Commons license, and indicate if changes were made. The Creative Commons Public Domain Dedication waiver (http://creativecommons.org/publicdomain/zero/1.0/) applies to the data made available in this article, unless otherwise stated. 


\section{Case presentation}

A 27-year-old male with a nodule on his left foot, which had been present for 5 years, was referred to our dermatology department. The patient stated that the nodule had grown slowly over the past few years. He was healthy, and his medical, surgical, and family history were all non-contributory. In a macroscopic examination, a $1-\mathrm{cm}$ exophytic, reddish, and hyperkeratotic nodule was noted on the dorsum of the left foot (Fig. 1). The lesion was completely resected and subjected to a histological examination. A microscopic examination of hematoxylin and eosin (H\&E)-stained slides performed at low magnification showed a nodular, dermal-based tumor surrounded by an epidermal collarette (Fig. 2). At higher magnification, the tumor was composed of cells with ovoid to round nuclei, small distinct nucleoli, and ill-defined eosinophilic cytoplasm (Fig. 3). Binucleated tumor cells were occasionally observed (Fig. 4). Based on the examination of the H\&E-stained sections, the differential diagnoses included a cutaneous CD30-positive lymphoproliferative disorder and so-called fibrohistiocytic tumors, including conventional FH, melanoma, Spitz nevus, and $\mathrm{ECH}$.

Immunohistochemically, the tumor cells showed cytoplasmic staining for factor XIIIa and ALK (the ALK staining was performed using both clone 5A4 (NICHIREI) (Fig. 5a) and an anti-ALK-1 antibody (DAKO) (Fig. 5b)), but were negative for AE1/AE3 keratin, alpha-smooth muscle actin, CD30, CD34, CD68, PU.1, melan A, MITF, and S-100 protein. The tumor's Ki-67 labeling index was 3.5\%.

Fluorescence in situ hybridization (FISH) analysis using $A L K$ break-apart probes produced a positive result, as indicated by the presence of isolated green $\left(5^{\prime} A L K\right)$ and orange $\left(3^{\prime} A L K\right)$ signals in the tumor cell nuclei, flanking the $A L K$ locus at 2p23 (Fig. 6).

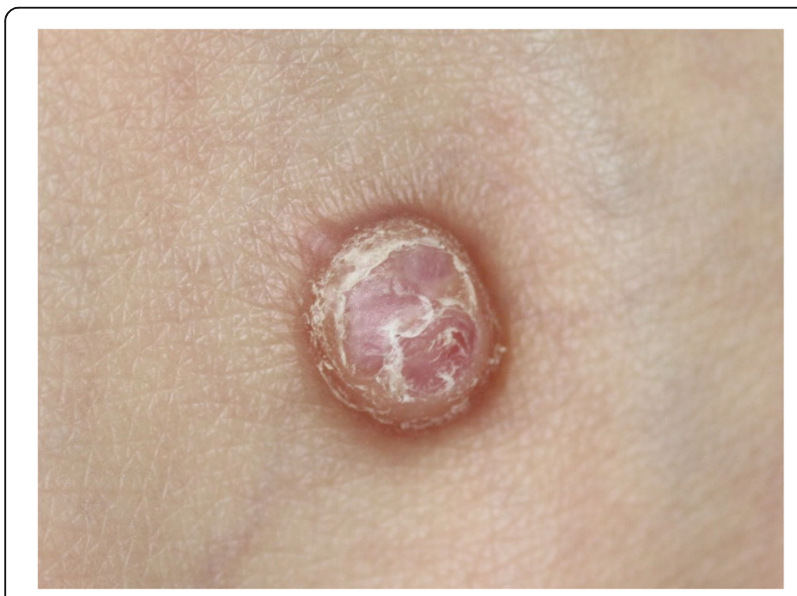

Fig. 1 Macroscopic appearance of the ECH. The lesion presented as a 1-cm exophytic, reddish, and hyperkeratotic nodule

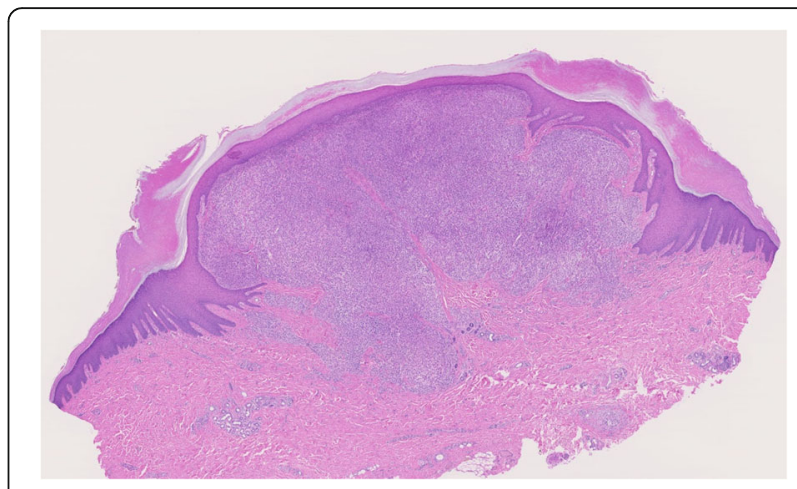

Fig. 2 A low-power microscopic view of the lesion revealing a nodular, dermal-based tumor surrounded by an epidermal collarette

The histological, immunohistochemical and cytogenetic findings were compatible with $\mathrm{ECH}$.

SQSTM1-ALK fusion, in which exon 5 of the SQSTM1 gene was fused to exon 20 of the $A L K$ gene, was detected with a $5^{\prime}$-rapid amplification of cDNA ends assay using RNA extracted from formalin-fixed paraffin-embedded tissue (Fig. 7a) [12]. To confirm the chromosome rearrangement, we performed reverse transcription polymerase chain reaction (RT-PCR) (Fig. 7b) and fusion FISH assays (Fig. 8) for SQSTM1-ALK. The results were also consistent with the presence of a $\mathrm{t}(2 ; 5)(\mathrm{p} 23.1 ; \mathrm{q} 35.3)$ translocation, leading to the generation of SQSTM1-ALK. A final diagnosis of ECH with SQSTM1-ALK gene fusion was made.

The patient was well and exhibited no evidence of tumor recurrence or metastasis at the 1-year of follow-up.

\section{Discussion}

ECH is a rare dermal neoplasm and is generally considered to be a morphological variant of FH. However, our case and recent reports suggest that $\mathrm{ECH}$ is actually a distinct entity, which displays a characteristic morphology,

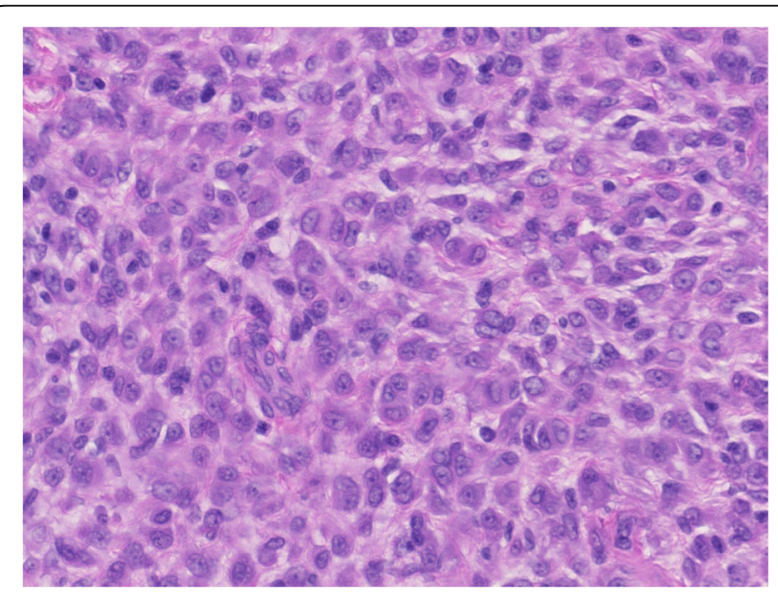

Fig. 3 Histological findings. The tumor was composed of sheets of epithelioid cells with eosinophilic cytoplasm 


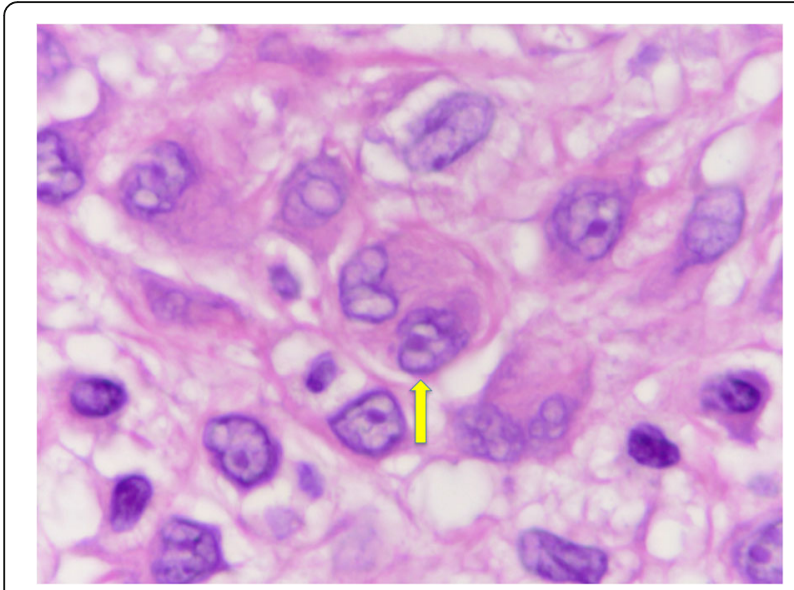

Fig. 4 A binucleated tumor cell (arrow)

ALK immunopositivity, and $A L K$ gene rearrangement. The differential diagnoses for ALK-positive tumors of the skin include ALK-positive anaplastic large cell lymphoma (ALK+ALCL) with or without systemic involvement [13] and Spitz tumors with $A L K$ fusion [14]. Since the cells of both of these tumors sometimes show histiocytoid or epithelioid arrangements, immunohistochemical panels including lineage-specific markers are critical for making a diagnosis of ECH. ALCL is always positive for CD30 and some T-cell markers, such as CD3, CD4, and cytotoxic molecules, whereas Spitz tumors are positive for melanocytic markers, such as melan A, MITF, and SOX10.

After first being identified in ALCL, ALK has been proven to be a versatile oncogene, which contributes to a variety of tumors, including those derived from

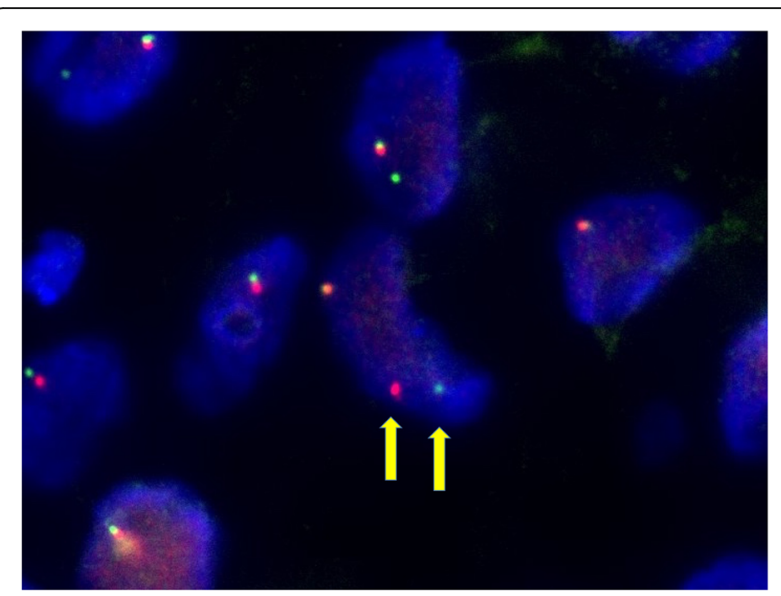

Fig. $6 \mathrm{FISH}$ analysis of $A L K$ rearrangement showing split $3^{\prime} A L K$ (orange) and $5^{\prime} A L K$ (green) signals (arrows)

hematolymphoid, epithelial, mesenchymal, melanocytic, and neural lineages $[15,16]$. Alterations in the ALK gene can occur through various different mechanisms, including chromosomal translocation, point mutations, and amplification. In chromosomal translocation, $A L K$ fusion proteins lead to ligand-independent constitutive activation of key pathways for oncogenesis and tumor progression.

It is interesting that each type of ALK-positive skin tumor seems to harbor a different common fusion gene. The findings of Jedrych et al. [6] and our data indicate that the SQSTM1-ALK can be a recurrent fusion gene in $\mathrm{ECH}$. The most recent large studies by two groups also suggest that SQSTM1-ALK is the most common fusion

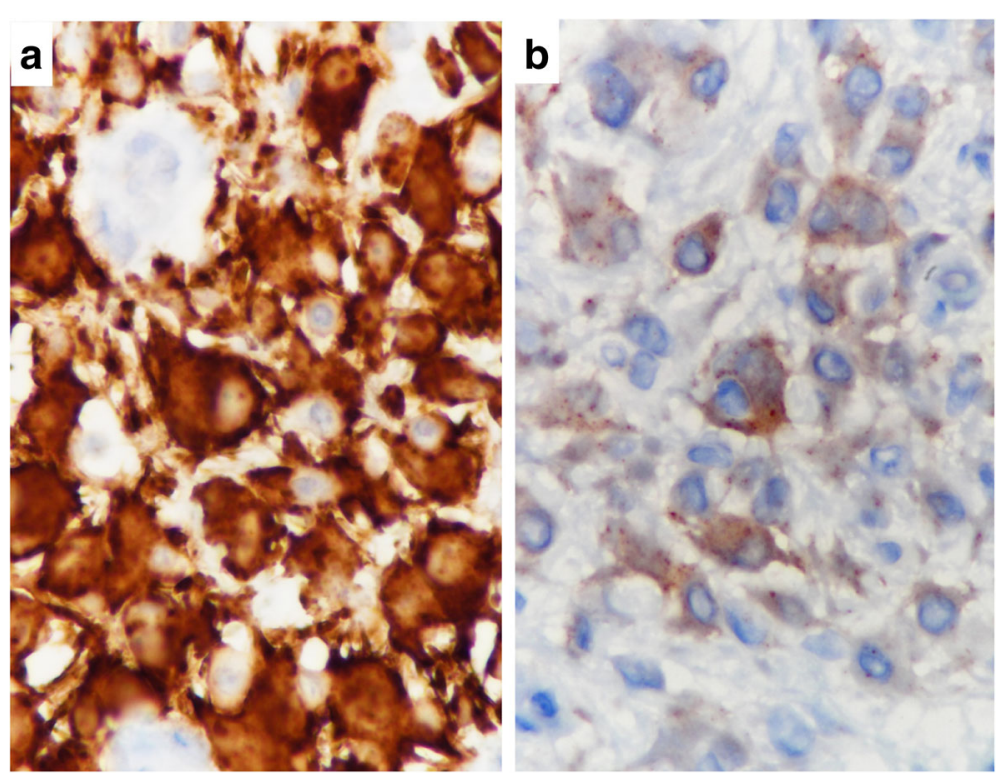

Fig. 5 Immunohistochemistry for ALK. The immunostaining was performed using both clone 5 A4 (a) and an anti-ALK-1 antibody (b) and demonstrated cytoplasmic staining 


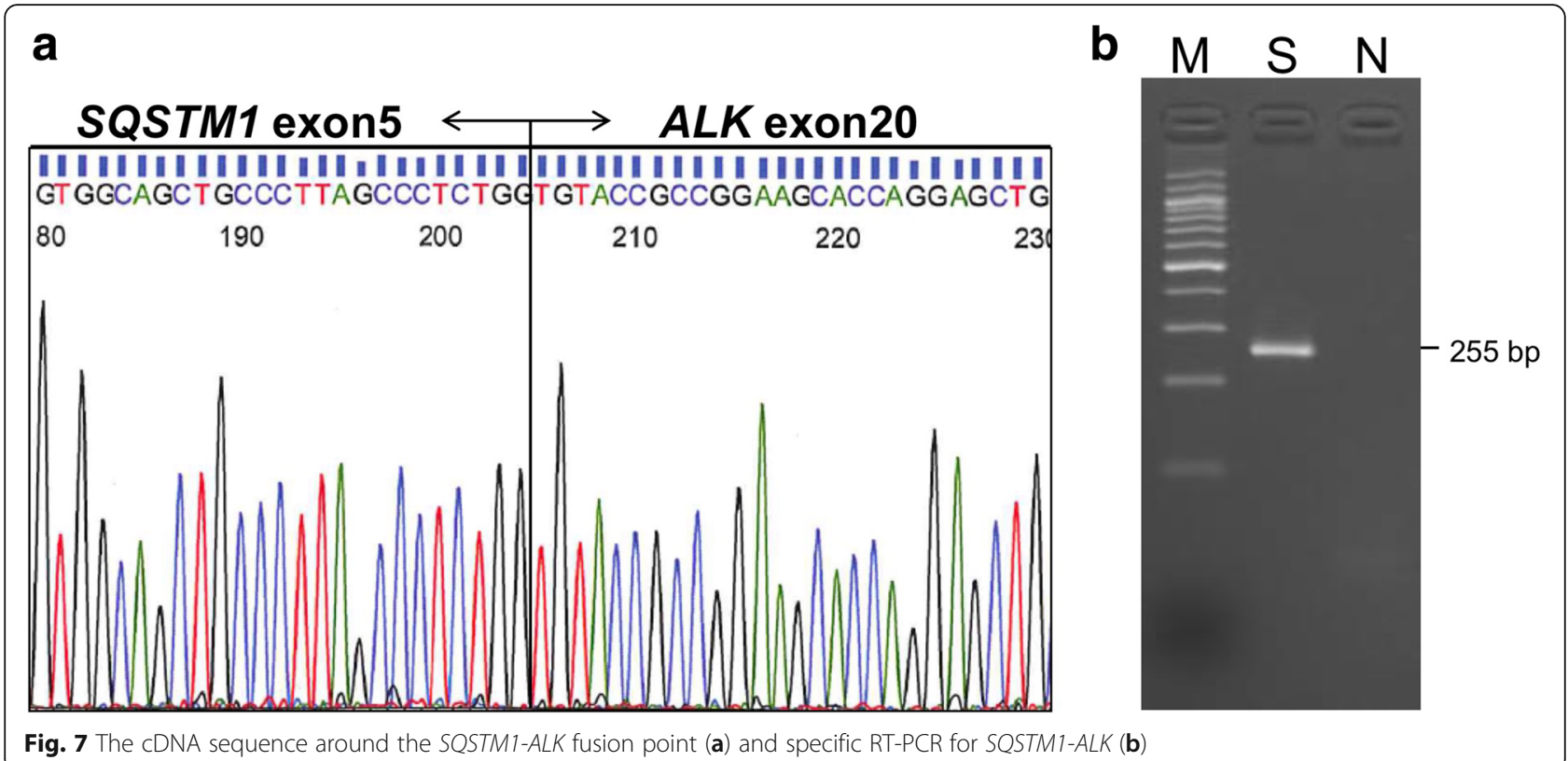

gene in $\mathrm{ECH}$, followed by $V C L-A L K[10,11]$. Other minor fusion partners include DCTN1, ETV6, PPFIBP1, SPECC1L, TMP3, PRKAR2A, MLPH, and EML4 [10, 11].

The SQSTM1 gene encodes sequestosome-1 (also known as the ubiquitin-binding protein p62), which acts as a cargo protein in selective autophagy. In addition to $\mathrm{ECH}$, SQSTM1-ALK has also been reported in some cases of ALK-positive large B-cell lymphoma and lung cancer [12, 17]. In contrast, ALK+ALCL, a kind of T-cell lymphoma, typically involves the NPM1-ALK or TPM3$A L K$ fusion gene [15]. In Spitz tumors, novel $A L K$ fusions, such as CLIP1-ALK and GTF3C2-ALK, have been

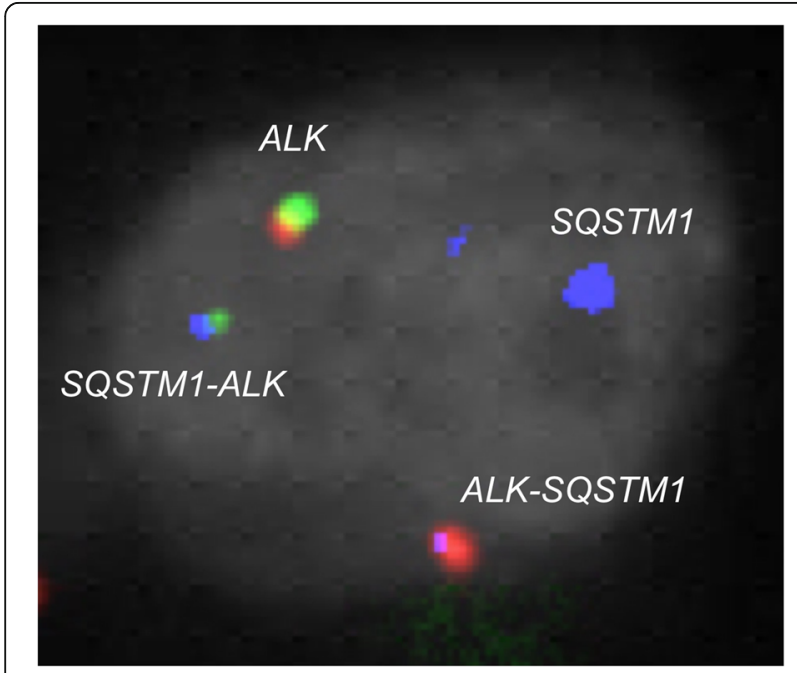

Fig. 8 Findings of fusion FISH for SQSTM1-ALK. 5'SQSTM1-3'ALK (blue-green) and 5'ALK-3'SQSTM1 (red-blue) signals were detected. Note that the colors of the probe flanking the breakpoint of the ALK gene are opposite to those seen in Fig. 6 discovered [14]. At present, the identification of a fusion gene partner of $A L K$ involves a complicated process, and a combination of $\mathrm{H} \& \mathrm{E}$ staining and immunohistochemistry is needed to make a definitive diagnosis of ALKpositive ECH. Although staining patterns are the same, our case and a previous report showed that 5A4 clone produced stronger staining intensity than ALK1 antibody [18].

$\mathrm{ECH}$ and conventional $\mathrm{FH}$ are considered to be benign neoplasms. However, Doyle et al. [5] reported a rare case of $\mathrm{ECH}$ involving multiple lung metastases. The patient died of the disease after wedge resection of the lung metastasis followed by radiotherapy. Doyle et al. did not mention the results of immunohistochemistry [5], and so it is unclear whether the tumor was ALK-positive. Since other rare cases of $\mathrm{FH}$ involving locally aggressive growth or metastasis have been reported [19], incomplete resection should be avoided.

\section{Conclusions}

We detected the SQSTM1-ALK fusion gene in a case of $\mathrm{ECH}$ exhibiting cytoplasmic ALK protein expression. This fusion gene might be the most common in $\mathrm{ECH}$. Lineage-specific immunohistochemistry is necessary to exclude other ALK-positive skin tumors, such as ALK +ALCL of the skin or Spitz tumor with ALK fusion.

\section{Abbreviations}

ALCL: Anaplastic large cell lymphoma; ALK: Anaplastic lymphoma kinase; ECH: Epithelioid cell histiocytoma; FH: Fibrous histiocytoma;

FISH: Fluorescence in situ hybridization

Availability of data and materials

Data sharing not applicable to this article as no datasets were generated or analysed during the current study. 


\section{Authors' contributions}

$\mathrm{RN}$ and $\mathrm{HH}$ wrote the manuscript. KT reviewed the case and designed the FISH probes. YT and SB performed in situ hybridization and PCR. YK collected the clinical data. TS and YT contributed to the pathologic diagnosis and made useful comments. All authors have read and approve the final manuscript.

\section{Ethics approval and consent to participate}

Not applicable

\section{Consent for publication}

Written informed consent for this research and publication was obtained from the patient. A copy of the consent form is available for review by the Editor of this journal.

\section{Competing interests}

The authors declare that they have no competing interests.

\section{Publisher's Note}

Springer Nature remains neutral with regard to jurisdictional claims in published maps and institutional affiliations.

\section{Author details}

'Department of Diagnostic Pathology, Kyoto University Hospital, Kyoto, Japan. ${ }^{2}$ Pathology Project for Molecular Targets, the Cancer Institute, Japanese Foundation for Cancer Research, Tokyo, Japan. ${ }^{3}$ Department of Dermatology, Kyoto University Hospital, Kyoto, Japan.

\section{Received: 5 February 2018 Accepted: 27 April 2018}

\section{Published online: 10 May 2018}

\section{References}

1. Jones EW, Cerio R, Smith NP. Epithelioid cell histiocytoma: a new entity. Br J Dermatol. 1989:120:185-95.

2. Glusac EJ, McNiff JM. Epithelioid cell histiocytoma: a simulant of vascular and melanocytic neoplasms. Am J Dermatopathol. 1999;21:1-7.

3. Cangelosi JJ, Prieto VG, Baker GF, Moore BA, Diwan AH. Unusual presentation of multiple epithelioid cell histiocytomas. Am J Dermatopathol. 2008;30:373-6.

4. Luzar B, Calonje E. Cutaneous fibrohistiocytic tumours - an update. Histopathology. 2010;56:148-65.

5. Doyle LA, Fletcher CD. Metastasizing "benign" cutaneous fibrous histiocytoma: a clinicopathologic analysis of 16 cases. Am J Surg Pathol. 2013;37:484-95.

6. Jedrych J, Nikiforova M, Kennedy TF, Ho J. Epithelioid cell histiocytoma of the skin with clonal ALK gene rearrangement resulting in VCL-ALK and SQSTM1-ALK gene fusions. Br J Dermatol. 2015;172:1427-9.

7. Doyle LA, Mariño-Enriquez A, Fletcher CD, Hornick JL. ALK rearrangement and overexpression in epithelioid fibrous histiocytoma. Mod Pathol. 2015:28:904-12.

8. Walther C, Hofvander J, Nilsson J, Magnusson L, Domanski HA, Gisselsson D, et al. Gene fusion detection in formalin-fixed paraffin-embedded benign fibrous histiocytomas using fluorescence in situ hybridization and RNA sequencing. Lab Investig. 2015;95:1071-6.

9. Creytens D, Ferdinande L, Van Dorpe J. ALK rearrangement and overexpression in an unusual cutaneous epithelioid tumor with a peculiar whorled "Perineurioma-like" growth pattern: epithelioid fibrous histiocytoma. Appl Immunohistochem Mol Morphol. 2017;25:e46-8.

10. Dickson BC, Swanson D, Charames GS, Fletcher CD, Hornick JL. Epithelioid fibrous histiocytoma: molecular characterization of ALK fusion partners in 23 cases. Mod Pathol. 2018; https://doi.org/10.1038/modpathol.2017.191. [Epub ahead of print]

11. Kazakov DV, Kyrpychova L, Martinek P, Grossmann P, Steiner P, Vanecek T, et al. ALK gene fusions in epithelioid fibrous histiocytoma: a study of 14 cases, with new histopathological findings. Am J Dermatopathol. 2018; https://doi.org/10.1097/DAD.0000000000001085. [Epub ahead of print]

12. Togashi Y, Soda M, Sakata S, Sugawara E, Hatano S, Asaka R, et al. KLC1-ALK: a novel fusion in lung cancer identified using a formalin-fixed paraffinembedded tissue only. PLoS One. 2012;7:e31323.

13. Beylot-Barry M, Lamant L, Vergier B, de Muret A, Fraitag S, Delord B, et al. Detection of $\mathrm{t}(2 ; 5)(\mathrm{p} 23 ; \mathrm{q} 35)$ translocation by reverse transcriptase polymerase chain reaction and in situ hybridization in CD30-positive primary cutaneous lymphoma and lymphomatoid papulosis. Am J Pathol. 1996;149:483-92.
14. Yeh I, de la Fouchardiere A, Pissaloux D, Mully TW, Garrido MC, Vemula SS, et al. Clinical, histopathologic, and genomic features of Spitz tumors with ALK fusions. Am J Surg Pathol. 2015;39:581-91.

15. Chiarle R, Voena C, Ambrogio C, Piva R, Inghirami G. The anaplastic lymphoma kinase in the pathogenesis of cancer. Nat Rev Cancer. 2008:8:11-23.

16. Mano H. ALKoma: a cancer subtype with a shared target. Cancer Discov. 2012:2:495-502.

17. Iyevleva AG, Raskin GA, Tiurin VI, Sokolenko AP, Mitiushkina NV, Aleksakhina SN et al. Novel ALK fusion partners in lung cancer. Cancer Lett. 2015;362:116-21.

18. Selinger Cl, Rogers TM, Russell PA, O'Toole S, Yip P, Wright GM, et al. Testing for ALK rearrangement in lung adenocarcinoma: a multicenter comparison of immunohistochemistry and fluorescent in situ hybridization. Mod Pathol. 2013:26:1545-53.

19. Gleason BC, Fletcher CD. Deep "benign" fibrous histiocytoma: clinicopathologic analysis of 69 cases of a rare tumor indicating occasional metastatic potential. Am J Surg Pathol. 2008;32:354-62.

\section{Ready to submit your research? Choose BMC and benefit from:}

- fast, convenient online submission

- thorough peer review by experienced researchers in your field

- rapid publication on acceptance

- support for research data, including large and complex data types

- gold Open Access which fosters wider collaboration and increased citations

- maximum visibility for your research: over $100 \mathrm{M}$ website views per year

At BMC, research is always in progress.

Learn more biomedcentral.com/submissions 